\title{
Fenomenologia procesem autokonstytucji, ti. zradzania się podmiotu do właściwego mu bycia? Refleksja wokół antropologiczno-mistycznych wątków twórczości Edmunda Husserla'
}

DOI: http://dx.doi.org/10.12775/RF.2016.002

\begin{abstract}
„Drogi przyjacielu, muszę wyznać to po raz kolejny. Stałem się filozoficznym eremita, niezależnym od wszystkich «szkół», a przecież myślącym codziennie o Bogu, który dał mi jeszcze do zaprojektowania (...) system fenomenologicznej filozofii"2.
\end{abstract}

Pomimo, iż na ogół fenomenologię Edmunda Husserla odczytuje się w duchu teorii poznania, pojmując ją jako metodę, której celem jest osiągnięcie, na drodze złożonych oraz żmudnych ćwiczeń, widzenia czystego i niczym niezmąconego, to zmiana perspektywy percypowania rzeczy na immanentna, którą ta miałaby nam zapewniać, nie wyczerpuje jeszcze w pełni przypisywanego jej przez samego Husserla sensu. Liczne, chociaż niekiedy bardzo rozproszone wypowiedzi fenomenolo$\mathrm{ga}^{3}$, które jednym razem przyjmują postać długich pasaży, innym razem

1 Niniejszy tekst został pierwotnie zaprezentowany w formie odczytu pod tym samym tytułem na seminarium Polskiego Towarzystwa Filozofii (Odział w Częstochowie) oraz Zakładu Filozofii AJD dnia 6. kwietnia 2016 roku.

2 E. Husserl, Brief an R. Ingarden, 11.VI.1932, w: Husserliana. Dokumente Briefwechsel. Die Freiburger Schule, Bd. III/IV, herg. K. Schuhmann, Kluwer Academic Publishers, Dordrecht 1993, s. 286-287 (dalej HAU DOK III/III).

3 Chciałabym podziękować Fundacji KAAD za wsparcie moich badań nad niepublikowaną spuścizną Edmunda Husserla, zebraną w jego archiwum w Kolonii. Jestem również niezmiernie wdzięczna dyrektorowi Archiwum Husserla w Leuven 
jedynie krótkich, czy wręcz zdawkowych, lakonicznych słów, zdają się bowiem sugerować, iż fenomenologię można byłoby odczytywać jako swoistego rodzaju proces, w ramach którego jej adept staje przed zadaniem rozpoznania siebie $\mathrm{w}$ prawdzie własnego bytu oraz wzięcia siebie $\mathrm{w}$ jej świetle $\mathrm{w}$ posiadanie. $\mathrm{W}$ tym sensie fenomenologia byłaby swoistym procesem „,autokonstytucji podmiotu” (Selbstkonstitution) ${ }^{4}$ we właściwym mu byciu 5 .

Obierając powyższą linię interpretacyjną należałoby zatem postrzegać fenomenologię jako rodzaj pracy jej adepta nad sobą samym, której celem byłoby wydobycie przez niego z jego wewnętrznego uposażenia swoistego potencjału, który jako taki czeka wciąż na swoje urzeczywistnienie, a który określa jego ludzka natura. Ów potencjał bowiem to właściwy mu status ontologiczny, którym jest jego „ukryte ja” (das verborgene $(c h)^{6}$. Tym sposobem zmiana optyki widzenia przez nas rzeczy dokonująca się za sprawą fenomenologii niosłaby za sobą faktycznie swoiste antropologiczne implikacje, a ona sama byłaby ostatecznie niczym innym jak „Odbudową życia w absolutnej prawdziwości i pierwotności $(\ldots)^{\prime \prime 7}$. Co jednak istotne, ów powrót człowieka do niego samego na drodze fenomenologicznego ćwiczenia się w byciu sobą oraz idąca za tym jego wewnętrzna przemiana (Verwandlung) ${ }^{8}$, w wyniku której danym byłoby mu bytować na sposób źródłowy, zdają się ponadto nieść za sobą mistyczne implikacje, ponieważ owo "prawdziwe ja”

panu Profesorowi U. Melle za zgodę na wykorzystanie oraz cytowanie niepublikowanych tekstów Husserla, zebranych w jego archiwach. W niniejszym artykule będę odwoływała się zarówno do literatury opublikowanej, jak i niepublikowanej. W przypadku cytowań manuskryptów Husserla będę używała oficjalnych sygnatur oraz tytułów nadanych im przez archiwistów. Natomiast z racji tego, iż część manuskryptów dotyczących poruszanego w niniejszym artykule problemu została już fragmentarycznie opublikowana w ostatnim tomie Husserliana, lecz ich wydanie pozostaje niejasne i nieprzejrzyste ze względu na pozbawienie poszczególnych wątków myślenia Husserla kontekstu, będę w przypisach odsyłała zarówno do Husserliana, zgodnie z którymi będą przeze mnie cytowane teksty oraz samych manuskryptów.

4 E. Husserl, Husserliana. Grenzprobleme der Phänomenologie. Analysen des Unbewusstseins und der Instinkte. Metaphysik. Späte Ethik. Texte aus dem Nachlas (1908-1937), Bd. XLII, herg. R. Sowa, Springer, Dordrecht 2014, s. 441 (dalej HAU XLII); E. Husserl, B I 21 (4), Wissenschaft und Leben (...) Weg in die Philosophie von der Praxis her. Wissensbelege (...) Der Mensch als europäischer, die Umwelt als wissenschaftlich umgestaltete, die Kultur eine wissenschaftliche. Wissenschaft und Tradition. (...) Der griechische Mensch und seine Wissenschaft (1924-1925), s. 10 (dalej MS B I 21 (4)).

5 Por. HAU VI, op. cit., s. 140.

6 E. Husserl, A V 21, Ethisches Leben. Theologie - Wissenschaft (1924-1927), s. 49 (dalej MS A V 21).

7 HAU XLII, op. cit., s. 440.

8 Por. HAU VI, op. cit., s. 140. 
$\left(\right.$ wahres Ich) ${ }^{9}$ oraz "ja autenyczne" (echte Ich) ${ }^{10}$ człowieka, to zdaniem Husserla nic innego, jak skrywające się w głębi ludzkiego bytu „wieczne Dasein". Dlatego też fenomenologia, zgodnie z intuicjami filozofa, miała być koniec końców drogą prowadzącą człowieka poprzez doświadczenie siebie $\mathrm{w}$ faktyczności jego własnego bytu do samego Boga ${ }^{11} \mathrm{i}$ taki właśnie cel przyświecał jej - jak wyznawał Husserl w jednym ze swych listów do Arnolda Metzgera - wręcz od początku jego filozoficznej pracy. „Nie miałem wówczas - pisał fenomenolog - jeszcze wyrobionego spojrzenia na rzeczywistość praktyki i kultury, jeszcze żadnego rozpoznania ludzi i narodów, żyłem jeszcze wolą prawie wyłącznie teoretycznej pracy - choć decydujące bodźce (które popchnęły mnie od matematyki do zawodowego uprawiania filozofii) leżały w sferze przemożnych przeżyć religijnych i [związanej z nimi mojej] zupełnej przemiany. To bowiem potężny wpływ Nowego Testamentu na dwudziestotrzylatka wyraził się przecież w dążeniu, żeby przez ściśle filozoficzną naukę odnaleźć drogę do Boga i do życia w prawdzie"12. Co więcej, stworzenie drogi do Boga Husserl pojmował w kategoriach życiowego zadania (Lebensaufgabe) czy wręcz misji (Mission) ${ }^{13}$ powierzonej mu przez sam Absolut. „Ja pragnę tego samego, czego pragną Kościoły - wyznawał Husserl swojej uczennicy Adelgundis Jägerschmid - doprowadzić ludzkość do wieczności. Moim zadaniem jest próbować tego poprzez filozofię. Wszystko, co napisałem dotychczas, są to tylko prace wstępne: jest to jedynie wykuwanie metod. Do jądra, do tego co istotne, człowiek - niestety, w ciągu tylko jednego życia nie dojdzie. A jest rzeczą tak ważna, by od liberalizmu i racjonalizmu doprowadzić filozofię z powrotem do tego, co jest istotne, do prawdy. Przedmiotem każdej prawdziwej filozofii musi być kwestia bytu ostatecznego, prawdy. I to jest dziełem mojego ży wota"14.

9 HAU XLII, op. cit., s. 420; Edmund Husserl, A V 21, op. cit., , s. 20.

10 HAU XLII, op. cit., s. 394; Edmund Husserl, A V 21, op. cit., s. 15.

11 Por. E. Husserl und M. Husserl, Brief an G. Albrecht, 22.XII.1931, in: Husserliana. Dokumente Briefwechsel. Familienbriefe, Bd. III/IX, herg. S. Ijsseling, Kluwer Academic Publishers, Dordrecht, s. 79.

12 Edmund Husserl, List Edmunda Husserla do Arnolda Metzgera, "Przegląd Filozoficzny, , Warszawa 2009 (18), s. 538.

13 Husserl wielokrotnie używa obu zwrotów w swojej korespondencji np. z R. Ingardenem, D. Mahnkiem, L. Landgrebem, F. Kaufmannem, G. Albrechtem, Th. Celmsem (por. Husserliana Dokumente. Briefwechsel. Die Göttinger Schule, Bd. III/IV, herg. S. Ijsseling, Kluwer Academic Publishers, Dordrecht 1994; HAU DOK III/IV 1994; HAU DOK III/IX, 1994).

14 A. Jägerschmid, Rozmowy z Edmundem Husserlem (1931-1938), przeł. Z. Abrahamowicz, „ZNAK”, 1972 (212), s. 163. 


\title{
Ogólny zarys Husserlowskiej pracy sub spacie aeternitatis $^{15}$ - cele oraz zadania fenomenologicznej drogi do Boga ${ }^{16}$
}

\author{
Ukształtowany w duchu myślenia ścisłego oraz rzeczowego swego \\ pierwszego mistrza i wykładowcy matematyki, Karla Weierstrassa, Hus-
}

15 E. Husserl, Brief an F. Kaufmann, 15.IV.1933, in: HAU DOK III/IV, op. cit., s. 192.

16 Zdaje się, że na samym wstępnie zasadnym byłoby postawienie pytania o to, czy w przypadku Husserla będziemy mówić o Bogu filozofów czy Bogu Objawienia. Gdyby przyjrzeć się złożoności myślenia fenomenologa w tym temacie, który postrzegał Boga jako z jednej strony ",absolutny Logos”, ,,absolutnie idealną idee-biegun” czy „,idee najdoskonalszego bytu”, a z drugiej jako absolutny telos, „wszechświadomość" konstytuującą rzeczywistość czy obdarzające sobą wszelkie stworzenie Dobro, to odpowiedź na owo pytanie nie jest łatwa. $Z$ pewnością trudności w jej udzieleniu będzie przysparzać również zawiłość życia religijnego samego Husserla, który jeszcze jako młody student nawrócił się z judaizmu na protestantyzm, ale który pomimo to zawsze postrzegał się jako „,wolnego chrześcijanina” oraz „niedogmatycznego protestanta” (por. E. Husserl, Brief an R. Otto.5.III.1919, in: Husserliana Dokumente. Wissenschaftlerkorespondenz, Bd. III/VII, herg. S. Ijsseling, Kluwer Academic Publishers, Dordrecht 1994; HAU DOK III/VII 1994, s. 207). Ponadto prawdopodobnie $\mathrm{w}$ ostatnich latach swego życia Husserl przeżył powtórnie religijną konwersję, tym razem jednak na katolicyzm (por. G. Anders, Die Schrift an der Wand. Beck, München 1976; Adelgundis Jägerschmid, Rozmowy z Edmundem Husserlem (1931-1938). Być może pewne światło w niniejszej kwestii, mogłyby rzucić studia nad zachodzącymi podobieństwami pomiędzy myślą fenomenologa i chrześcijańską mistyką którą zresztą ten bardzo się inspirował. Jak twierdził bowiem sam Husserl kluczowy impuls, pod wpływem którego udało mu się odkryć oraz opracować redukcję fenomenologiczną, stanowiła lektura Wyznań św. Augustyna. Ponadto filozof zaczytywał się w Mistrzu Eckharcie, twierdząc, że całe ustępy z tekstów mistyka można byłoby bez żadnej korekty przenieść do jego własnych oraz średniowiecznym traktatem Teologia Niemiecka, który wpłynął na kształt całej niemieckiej mistyki. Husserlowi nie była obca także myśl Mikołaja z Kuzy, św. Anzelma oraz mistyka karmelitańska (por. D. Cairns, Conversations with Husserl and Fink. M. Nijhoff, The Hague 1976; Hans Drisch, Lebenserinnerungen, Reinhardt, München 1951; A. Jägerschmid, Rozmowy z Edmundem Husserlem (1931-1938)). Niestety, ze względu na zbytnią rozległość tematu, nie jestem w stanie nawiązać w żaden sposób do owych podobieństw. Ze względu na złożoność tematu, nie jestem również w stanie nawiazać do badań nad Husserlowskim pojęciem Boga, które są już w tej chwili dość zaawansowane (por. A.A. Bello, The Divine in Husserl and other Explorations, "Analecta Husserliana” XCVIII; L.C. Lo, Die Gottesauffassung in Husserls Phänomenologie, P. Lang, Frankfurt am Main 2008; E. Wolz-Gottwald, Transformation der Phänomenologie. Zur Mystik bei Husserl und Heidegger, Passagen Verlag, Wien 2009; Wilhelm Keilbach, Zu Husserls phänomenologischen Gottesbegriff, in: W. Keilbach (herg.), Religion und Religion. Gedanken zu ihrer Grundlegung, V.F. Schöninsch, Paderborn 1976; L. Landgrebe, Husserls phänomenologischer Zugangsweg zu den Problemen der Religion, in: W. Härle, E. Wölfel (herg.), Religion im Denken unserer Zeit, Elwert, Marburg 1986; K. Held, Gott in Edmund Husserls Phänomenologie, „Phaenomenologica”, 200 (5); K. Held, Phänomenologische Begründung eines nachmetaphysischen Gottesverständnis, in: K. Held, T. Söding (herg.), Phänomenologie und Theologie, Herder Verlag, Freiburg 2009). 
serl nie potrafił już u początków swej filozoficznej pracy wyobrazić sobie fenomenologii jako drogi do Boga inaczej, niż jako drogi ściśle racjonalnej ${ }^{17}$. To przecież również troska o kształt oraz rzetelność myślenia filozoficznego stanowiła, obok religijnych motywów zajęcia się przez niego filozofia, kluczowy powód wyboru takiej, a nie innej życiowej drogi.

Tym, co szczególne dla fenomenologicznej drogi człowieka do Boga miała być, w świetle powyższego, zdaniem Husserla, próba wzięcia $\mathrm{w}$ nawias - $\mathrm{w}$ imię osiągnięcia pełni obiektywności naszej refleksji - całości myślenia teologicznego oraz metafizycznego jako swoistego rodzaju zbiorów przedzałożeń, obfitujących w pewne z góry określone i nierzadko już utarte wyobrażenia Boga. W tym sensie Husserl miał nadzieję wziąć w nawias wszystkie tzw. "metafizyczne upiory”18 i spekulatywne konstrukcje Absolutu ${ }^{19}$, stwarzając możliwość "przedarcia” się człowieka do Niego samego. Jego zamiarem było zatem „przezwyciężenie" Boga w jakimś sensie nieobecnego, a przynajmniej ukrytego pod gęstą siecią metafizycznych oraz teologicznych pojęć - Boga, który przez to jest obcy człowiekowi, na rzecz Boga źródłowego, który pozostaje $\mathrm{w}$ pewnej bliskości względem naszego bytu, gdyż $\mathrm{w}$ gruncie rzeczy „(...) jest poznawalny jako Absolut z nas samych w fenomenologicznej redukcji $(\ldots)^{\prime 20}$. Dlatego też w swoim liście do Ericha Przywary, filozof zdecyduje się zdefiniować swoją fenomenologię ostatecznie jako ścieżkę „ateologicznych" ${ }^{21}$ poszukiwań Boga, a w rozmowach z siostrą Jägerschmid wyzna, iż jest to wręcz droga "do Boga bez Boga". „Życie ludzkie - wyznawał 4 września 1935 roku - jest niczym innym jak drogą do Boga. Ja staram się osiągnąc ten cel bez dowodów, metod, podbudówek teologii, to znaczy dojść do Boga bez Boga. W swojej egzystencji uczonego muszę niejako eliminować Boga, po to, by utorować drogę do Boga ludziom takim, którzy w odróżnieniu od siostry nie posiadają pewności wiary poprzez Kościół. Ja wiem, że takie moje postępowanie mogłoby być niebezpieczne dla mnie samego, gdybym sam nie był człowiekiem głęboko przywiązanym do Boga i wierzącym w Chrystusa"22. Jak możemy tylko mniemać, podobny zamysł - gdyby przyjrzeć się detalicznie wypowiedziom Husserla - fenomenolog pragnął wyrazić już w punkcie 58 swoich Idei pt. „O wyłączeniu transcendensu jakim jest Bóg", który wielokrotnie bywa błędnie odczytywany jako swoistego ro-

17 Por. E. Husserl, List Edmunda Husserla do Arnolda Metzgera, „Przegląd Filozoficzny,.,' Warszawa 2009 (18), s. 538; Eberhard Avé-Lallemant, Edmund Husserl zu Metaphysik und Religion, in: H. M. Gerlach H.-M., H. Rainer Sepp (herg.), Husserl in Halle, Peter Lang, Frankfurt am Main 1994, s. 105.

18 E. Husserl, List Edmunda Husserla do Arnolda Metzgera, op. cit., s. 538.

19 E. Husserl und M. Husserl, Brief an G. Albrecht, 22.XII. 1931, op. cit., s. 79.

20 Ibidem.

21 Idem, Brief an E. Przywara,15.VII.1932, in: HAU DOK III/VII, op. cit., s. 237.

22 A. Jägerschmid, Rozmowy z Edmundem Husserlem (1931-1938), op. cit., s. 168. 
dzaju deklaracja ateizmu filozofa bądź przynajmniej jako jego metodologiczny nakaz, w myśl którego każdy z adeptów jego metody już u początków swych badań powinien wykluczyć z nich Absolut, jeśli w ogóle go nie zanegować. Gdyby jednak zastosowanie fenomenologicznej redukcji było faktycznie każdorazowo tożsame z aktem negacji bądź wykluczenia przez nas z naszych intelektualnych poszukiwań obejmowanego przez nią właśnie bytu, to badaniem czego miałby zajmować się koniec końców fenomenolog? Sensem redukcji fenomenologicznej nie jest przecież podważenie $\mathrm{w}$ istnieniu badanej przez nas rzeczy, lecz nieczynienie użytku z tezy naturalnego nastawienia, zakładającej z góry owo jej istnienie ${ }^{23}$. Co więcej, w punkcie 58 swoich Idei, Husserl twierdzi, iż tylko takie metodologiczne postępowanie pozwoli nam faktycznie odkryć Boga: jeśli stanie się dla nas jasną racjonalność świata, odkryjemy wraz z nią pozaświatową jej zasadę, którą jest właśnie Absolut. „Redukcja świata naturalnego - twierdził w Ideach Husserl - do absolutu świadomości daje (ergibt) faktyczne związki przeżyć świadomościowych o pewnych określonych ukształtowaniach z wyróżnionymi prawidłowymi uporządkowaniami, w których konstytuuje się jako intencjonalny odpowiednik pewien w sferze empirycznej naoczności morfologicznie uporządkowany świat (...). Właśnie ten świat - jeżeli chodzi o jego najniższą warstwę materialną - da się zarazem w teoretycznym myśleniu matematycznego przyrodoznawstwa określić jako «zjawisko» fizykalnej przyrody podlegającej ścisłym prawom przyrodniczym. W tym wszystkim tkwi jakaś cudowna celow ość, gdyż racjonalność, jaką ten fakt urzeczywistnia, nie jest racjonalnościa, której domaga się istota. (...) Nie fakt w ogóle, lecz fakt jako źródło narastających w nieskończoność możliwości wartości i urzeczywistnień wartości zmusza do postawienia pytania o «podstawę» [tego wszystkiego - M.A.], podstawę naturalnie nie w sensie jakiejś rzeczowo kauzalnej przyczyny"24. Przy czym transcendens, jakim jest Bóg, jest bytem absolutnym w szczególnym sensie, gdyż jako taki transcenduje On sobą nie tylko świat, lecz również absolutne residuum, jakim jest ludzka świadomość, nie mogąc być do tej w żaden sposób redukowalnym. Mówiąc inaczej, boski atrybut absolutności nie jest tożsamy z absolutnością którą cechuje się nasza świadomość25. „Tym, co nas tutaj - kontynuował swoją myśl Husserl obchodzi, jest - po napomknięciu tylko o różnych grupach takich ro-

23 Por. A.A. Bello, A. A, The Divine in Husserl and other Explorations, w: A.-T. Tymieniecka (red.), Analecta Husserliana XCVIII, s. 27; L. C. Lo, Die Gottesauffassung in Husserls Phänomenologie, Peter Lang, Frankfurt am Main 2008, s. 64-65.

24 E. Husserl, Idee czystej fenomenologii i fenomenologicznej filozofii, przeł. D. Gierulanka, PWN, Warszawa 1975, s. 176-177.

25 Por. A.A. Bello, The Divine in Husserl and other Explorations, op. cit., s. 27; L.C. Lo, Die Gottesauffassung in Husserls Phänomenologie, Peter Lang, Frankfurt am Main 2008, s. 63-64. 
zumowych podstaw dla istnienia jakiegoś pozaświatowego «boskiego» bytu - to, że byłby on transcendentny nie tylko w stosunku do świata, lecz oczywiście także w stosunku do «absolutnej» świadomości. Byłyby zatem czymś «absolutnym» w pewnym zupełnie innym sensie niż absolut świadomości, tak jak z drugiej strony byłby czymś transcendentnym $\mathrm{w}$ zupełnie innym sensie $\mathrm{w}$ przeciwstawieniu do transcendensu w sensie świata" ${ }^{26}$.

Fenomenologia jako ścisła oraz racjonalna droga rozumu do Boga miała być w przekonaniu Husserla drogą paralelną do drogi Objawienia $^{27}$, a zatem $\mathrm{w}$ żadnym wypadku nie stojącą $\mathrm{z}$ tą $\mathrm{w}$ jakiejś wewnętrznej opozycji bądź napięciu. Jako taka miała być ona jedynie pewnego rodzaju alternatywą dla człowieka współczesnego ${ }^{28}$, do którego w zsekularyzowanym oraz zlaicyzowanym świecie Objawienie coraz częściej nie potrafi już dotrzeć, a który pomimo wszystko jakoś instynktownie może wciąż poszukiwać Absolutu, będąc gotowym w swoich poszukiwaniach jedynie do zawierzenia rozumowi. „Moja fenomenologia - wyznawał Husserl siostrze Adelgundis - nie pragnie być niczym innym jak drogą metoda przy pomocy której wskazuje się drogę powrotu do Boga ludziom, którzy odeszli właśnie od chrześcijaństwa i od chrześcijańskich kościołów"29 - ludziom, których na ogół ogarnął w XX-tym wieku duchowy oraz egzystencjalny kryzys, będący w gruncie rzeczy skutkiem wewnętrznego pęknięcia $\mathrm{w}$ łonie nauk. Nauki bowiem, roszcząc sobie prawo do zwalczania wszelkich przesądów, nie uczyniły w oświeceniu oraz pozytywizmie nic innego, jak ugruntowały kolejne i nowe, tym razem jednak przesądy naukowego światopoglądu, stając się tym samym formą "racjonalizmu naiwnego"30 i owocem „leniwego rozu$\mathrm{mu}^{\prime \prime 31}$. Z kolei, rozpowszechniając wszędzie swój „zabobon faktu”32 i „przeinterpretowując" wszystko to, co idealne ${ }^{33}$, tj. wszelkie normy, prawa oraz wartości na to, co względne, uczyniły one świat koniec końców bezsensownym oraz irracjonalnym, pozostawiając człowieka w jego bytowaniu jemu samemu. „Gdyby to jeszcze - komentował całe zajście

26 Ibidem, s. 177.

27 Por. A. Jägerschmid, Rozmowy z Edmundem Husserlem, op. cit., s. 159.

28 Por. E. Avé-Lallemant, Edmund Husserl zu Metaphysik und Religion, op. cit., s. 107.

29 A. Jägerschmid, Rozmowy z Edmundem Husserlem (1931-1938), op. cit., s. 174; E. Husserl, List Edmunda Husserla do Arnolda Metzgera, op. cit., s. 538.

30 E. Husserl, Kryzys nauk europejskich i fenomenologia transcendentalna. Wprowadzenie do filozofii transcendentalnej, przeł. S. Walczewska, Papieska Akademia Teologiczna, Kraków 1987, s. 13.

31 Ibidem, s. 14.

32 Idem, Filozofia jako nauka ścisła, przeł. W. Galarowicz, PWN, Warszawa 1992, s. 73.

33 Por. Ibidem. 
Husserl - tym, co mąci nasz spokój była tylko teoretyczna niejasność, co do sensu i « realności» badanych w naukach przyrodniczych oraz humanistycznych - co do tego mianowicie, w jakiej mierze poznajemy w nich byt w ostatecznym sensie, co trzeba uznać za taki «absolutny» byt i czy jest on w ogóle możliwy do poznania. Tym jednak, na co cierpimy, jest raczej najbardziej radykalna nędza życiowa, nędza, która nie ustaje w żadnym momencie naszego życia. Wszelkie życie jest zajmowaniem postaw, wszelkie zajmowanie postaw dokonuje się w zasięgu jakiejś powinności, jakiejś instancji, która wyrokuje o prawomocności lub nieprawomocności zgodnie z normami pretendującymi do absolutnej mocy obowiązującej. Dopóki normy te były nienaruszone, niezagrożone, ani nie wyśmiane przez żaden sceptycyzm, istniała tylko jedna kwestia życiowa: w jaki sposób najlepiej sprostać im w praktyce. Jak jednak jest teraz, gdy wszystkie bez wyjątku normy zostały zakwestionowane lub empirycznie zafałszowane i pozbawione swej idealnej mocy?"34. Przy czym tym, co zostało zakwestionowane oraz zafałszowane w XX. wieku przez nauki, są nie tylko idealne normy oraz wartości, lecz również sam byt człowieka, który w świetle naukowej wykładni świata stał się także nagim i nic nieznaczącym faktem. Najgorsze w tym wszystkim sa, zdaniem Husserla, nie tyle same nadużycia, których dopuściły się nauki w swoim ujęciu rzeczy, lecz to, iż człowiek owym nadużyciom dał ostatecznie wiarę, w skutek czego zarzucił on wszelkie starania, aby wydobyć z siebie jeszcze nie tak dawno przeczuwany przez niego potencjał, który określa przecież jego ludzka natura. W zamian za to, pozwolił on ogarnąć siebie swoistemu marazmowi i znużeniu, jakiegoś rodzaj gnuśności oraz ogólnemu zmęczeniu własnym byciem. Stąd jego ciągły sceptycyzm względem wszystkiego, który niekiedy zradza z siebie wręcz jakieś nihilistyczne nastawienie wobec życia jako takiego. Ów człowiek, mówiąc krótko, przestał pragnąć być tym, kim winien faktycznie być, tzn. nie chce stawać się coraz bardziej sobą, gdyż już nie wierzy, że jest kimś „,więcej” aniżeli jednym z wielu zwykłych faktów nie wierzy „(..) we właściwe mu istnienie, którego nie posiada przecież na stałe, wraz z oczywistością «ja jestem», lecz ma i mieć tylko może w postaci zmagań o swą prawdę, o to by siebie samego uczynić prawdziwym" ${ }^{\prime 3}$. W ten jednak sposób człowiek XX. wieku już nie tylko myśli podług naukowego światopoglądu, lecz również bytuje, a ów sposób istnienia w swoistego rodzaju ",naiwno-ludzkiej przytomności”" ${ }^{36}$, kiedy ten bierze rzeczy podług tego tylko, jakimi te zdają się mu "tu i teraz" być, przyjmując odpowiadający temu sposób egzystencji, to nic innego,

34 Ibidem, s. 72-73.

35 Idem, Kryzys nauk europejskich i fenomenologia transcendentalna. Wprowadzenie do filozofii transcendentalnej, op. cit., s. 10-11.

${ }^{36}$ Idem, B IV (5) Meditation (1933), s. 37 (dalej MS B IV (5)). 
zdaniem Husserla, jak naturalne nastawienie ${ }^{37}$. Tym samym naturalne nastawienie od tej pory przestaje być dla fenomenologa wyłącznie kategorią epistemologiczną, przejmując rolę kategorii antropologicznej, diagnozującej kondycję człowieka w czymś, co można byłoby nazwać codziennością czy nawet potocznością jego bycia, a czego tylko jednym z egzemplarycznych przykładów będzie dla Husserla kryzys człowieka współczesnego. Naturalne nastawienie jako kategoria antropologiczna określać będzie po prostu egzystencję człowieka, która ufundowana jest w pewnym już utartym, a przez to tradycyjnym sposobie percypowania rzeczywistości, który determinując pewien z góry określony i w pełni zgodny z sobą sposób bycia człowieka, prowadzi do tego, iż nasza osoba staje się „wewnętrznie pęknięta”, gdyż nie pozostaje ona w żadnym związku i koherencji z naszą ludzką naturą ${ }^{38}$. Jest to, inaczej mówiąc, stan permanentnego mijania się człowieka z jego własnym bytem - stan trwania w jakiejś nieprawdzie, kiedy zdradza on na swój sposób samego siebie.

Pojmując swoją fenomenologię jako drogę człowieka do Boga, która zarazem stanowiłaby odpowiedź na XX-wieczny kryzys człowieka, Husserl oczekiwał od niej, iż ta w gruncie rzeczy stanie się lekarstwem oraz terapią dla człowieka współczesnego. $W$ ten sposób stawiał on przed nią dwa fundamentalne zadania, twierdząc iż musi ona (1) doprowadzić na drodze dekonstrukcji świadomości potocznej do odnowy ludzkiego myślenia tak, aby człowiek odkrył „ostatecznie prawdziwą rzeczywistość" (letztwahre Wirklichkeit) ${ }^{39}$ - rzeczywiste środowisko wydarzania się jego egzystencji, którym jest świat życia (Lebenswelt) ${ }^{40}$. (2) Odkrywając świat w jego źródłowości i autentyczności, człowiek powinien odkryć i zarazem pochwycić siebie w swej prawdzie, a zatem wewnętrznie odnowić i przemienić (sich wandeln) własny byt $\mathrm{t}^{41}$. W tym sensie fenomenologia przypominałaby sobą platońską anamnezę, którą jednak należałoby pojmować nie jako „(...) powtórne przypomnienie (Wiedererinnerung), lecz osiągnięcie harmonii z samym sobą"42

37 Por. Ibidem; E. Wolz-Gottwald, Die Transzendentale Phänomenologie und die philosophische Mystik. Zum Durchbruch eines neuen Denkens im Spätwerk Edmund Husserls, Philosophisches Jahrbuch, 101 (1994), s. 109; Eckard Wolz-Gottwald, Zur Metabasis im Spätwerk Edmund Husserls, Allgemeine Zeitschrift für Philosophie 1995 (101), s. 124.

38 Por. MS B I 21 (4), op. cit., s. 97.

39 Edmund Husserl, Husserliana VIII, Erste Philosophie (1923/1924) Zweiter Teil: Theorie der phänomenologischen Reduktion, herg. R. Boehm, Martinus Nijhoff, Haag 1959, s. 166 (dalej HAU VIII); por. Eckard Wolz-Gottwald, Transformation der Phänomenologie. Zur Mystik bei Husserl und Heidegger, Passagen Verlag, Wien 1999, s. 106-107 .

40 Ibidem.

41 HAU XLII, op. cit., s. 319; MS F I 24, op. cit., s. 80.

${ }^{42}$ HAU XLII, op. cit.., s. 177; MS A 5 21, op. cit., s. 107. 
(Selbstverständigung) przez podmiot - proces jego identyfikacji siebie z sobą samym ${ }^{43}$. „Być może - pisał Husserl określając swoje naukowe cele oraz plany - uda się wykazać, że całkowicie fenomenologiczne nastawienie i przynależące do niego fenomenologiczne epoché są powołane ze swej natury w pierwszej kolejności do tego, by doprowadzić do całkowitej osobowej przemiany (personale Verwandlung) [człowieka M.A.], która mogłaby zostać porównana najpierw do religijnej konwersji, jednakże która ponadto skrywa w sobie znaczenie egzystencjalnej przemiany, zadanej ludzkości jako ludzkości"44 - wewnętrznej jej metanoi, która - jak zobaczymy później - ma pozwolić osiągnąć nam jedność (Einstimmigkeit) ${ }^{45}$, która będzie nie tylko jednością naszego bytu z nim samym, lecz również zarazem pewnym rodzajem koegzystencji bytu skończonego z wiecznym.

\section{Redukcja fenomenologiczna elementem ascetycznej formacji ludzkiego ducha}

Husserl sądził, iż najdonioślejszym odkryciem w ramach jego filozoficznej pracy było odkrycie redukcji fenomenologicznej jako metodologicznego narzędzia, udzielającego nam dostępu do rzeczy samej. W swoim liście do Ludwiga Landgrebego z dnia 14. listopada 1936 roku zapewniał swojego ucznia, iż „dla prawdziwych fenomenologów świat w końcu wygląda całkowicie inaczej. Dopiero w redukcji fenomenologicznej odsłania się prawdziwa i nieskończona «metafizyczna» głębia"46. Jednocześnie fenomenolog był przez całe swe życie głęboko przekonany, iż żadnemu z jego uczniów nie udało się odkryć właściwego sensu fenomenologicznego epoché, co niejednokrotnie miewał im zresztą za złe. Być może owo niezrozumienie myśli Mistrza ze strony uczniów wyrastało z już wtedy silnej tendencji do odczytywania rozważań Husserla w duchu teorii poznania. Tymczasem zdaje się, że właściwym przedmiotem zastosowania redukcji fenomenologicznej miała być, zdaniem filozofa, nie tyle jakakolwiek transcendentna rzecz, którą badamy na drodze fenomenologicznego namysłu oraz opisu, lecz sam człowiek. Kończąc swe Medytacje kartezjańskie Husserl pisał o tym w ten sposób: „Delfickie słowa gnothi seauton uzyskały nowe znaczenie (...). Trzeba najpierw stracić (verlieren) świat poprzez dokonanie epoché, by go potem na drodze

\footnotetext{
43 Por. MS B I 21 (4), op. cit., s. 97.

44 HAU VI, op. cit., s. 140.

45 Por. MS B I 21 (4), op. cit., s. 97.

46 E. Husserl, Brief an L. Landgrebe, 14.XI.1936, in: HAU DOK III/IV, op. cit., s. 361.
} 
uniwersalnej autorefleksji na powrót odzyskać. Noli foras ire, mówi Augustyn, in te redi, in interiore homine habitat veritas" ${ }^{47}$.

Jeśli by przyjąć powyższą krótką charakterystykę redukcji fenomenologicznej za w jakiś sposób obowiązująca, można byłoby powiedzieć, iż ta jest: 1) rodzajem kontemplacji siebie oraz medytacji podmiotu na sobą samym, w ramach których ten powoli oraz stopniowo zwracałby się ku sobie samemu (Innenwendung) ${ }^{48}$, koncentrując swoje badawcze i reflektujące spojrzenie tylko na nim samym. W tym sensie - jak zaznaczał gdzie indziej Husserl - kierunek redukcji byłby tożsamy z kierunkiem modlitwy, poprzez którą człowiek religijny szuka możliwości zbudowania autentycznego związku z Absolutem, a przez to - jak wierzy - możliwości osiągnięcia życia w jego prawdzie. „Ów kierunek [modlitwy - M. A.] do naszego wnętrza - pisał fenomenolog - jest paralelny z fenomenologicznym kierunkiem ku wnętrzu [człowieka - M.A.], ponieważ poprzez moje wnętrze prowadzi droga (...) dopiero do świata, do mnie samego i innego ludzkiego Dasein"49. 2) Redukcja fenomenologiczna stanowiłaby ponadto rodzaj narzędzia, za pomocą którego podmiot wręcz "wchodziłby” do wnętrza samego siebie w celu „wydobycia” poznania "duchowych rzeczy" które, jak wyznawał Husserl w jednym ze swych listów, "(...) jedynie z najgłębszego źródła istoty ludzkiej wypływają i budzą w śpiących duszach (in der schlafenden Seelen) ducha"50 do poznania. Celem owej powoli dokonującej się tutaj zmiany optyki widzenia rzeczy na immanentną będzie oczywiście osiągnięcie słynnego Wesensschau fenomenologa, który jako "transcendentalny" ogląd rzeczy przypominałby widzenie opisywane już niegdyś przez mistyków. „Poznanie oglądowe - definiował wgląd ejdetyczny Husserl - jest rozumieniem, które stawia sobie za cel doprowadzenie rozumowania właśnie do rozumienia. Rozumowaniu nie wolno tutaj wtrącać się i przemycać swoich wystawionych in blanco papierów bez pokrycia między takie, które mają wartość, zaś jego metoda wymieniania i przeliczania, która opiera się tylko na bonach skarbowych «i w ten sposób - można by też powiedzieć - ratuje swoje weksle» zupełnie nie wchodzi tutaj w grę. Zatem możliwie mało rozumowania, ale możliwie czyta intuicja (intuitio sine comprehension); faktycznie nawiązujemy do sposobu wyrażania się mistyków, gdy ci opisują ogląd intelektualny nie będący wiedzą rozumową. Cała zaś sztuka polega na tym, by dopuścić do głosu oglądające oko i wyłączyć przy tym wszystkie splecione z oglą-

47 Idem, Medytacje kartezjańskie, przeł. A. Wajs, PWN, Warszawa 1982, s. 236.

48 Por. HAU XLII, op. cit., s. 246; K. Held, Lebendige Gegenwart, in: Phaenomenologica 23, Martinus Nijhoff, Haag 1966, s. 180.

49 HAU XLII, op. cit., s. 247; E III 9, Enthüllungsgang der universalen Teleologie als Gang der gesamten Konstitution von den Anfängen an, 1930-1931, s. 22.

50 E. Husserl, Brief an A. Jägerschmid, 18.X.1936, in: HAU DOK III/IV, op. cit., s. 169. 
daniem domniemanie transcendujące, rzekome posiadanie [czegoś] jako współdanego, [wyłączyć] to, co współmyślane i ewentualnie to, co dodatkowo winterpretowane przez dołączającą się refleksję" ${ }^{\prime \prime 1}$. 3) Z racji tego, iż owo „wchodzenie" podmiotu do wnętrza siebie musi przebiegać według ściśle określonych, metodologicznych kroków, przewidzianych $\mathrm{w}$ ramach samej redukcji, to ona sama może przypominać nam proces powolnego oraz systematycznego uwalniania (Befreiung) $)^{52}$ naszej świadomości z tego, co dla badanej przez nas właśnie rzeczy przypadkowe oraz względne - proces „oczyszczania” naszego myślenia z potocznego ujęcia rzeczy. Przy czym jako taki, ów proces, zgodnie z zamysłem Husserla, ma dokonywać się nie tylko na poziomie poznawczym naszej egzystencji, lecz również bytowym ${ }^{53}$, gdyż jak filozof wspomina krótko i zdawkowo, $\mathrm{w}$ ramach przeprowadzonego przez nas fenomenologicznego epoché ma dochodzić do zogniskowania, a następnie osadzania całej naszej duchowej aktywności, a zatem nie tylko myślenia, lecz również przeżywania czy działania $\mathrm{w}$ nas samych $^{54}$. Zdaniem fenomenologa, w wyniku redukcji stawałoby się po prostu możliwym zebranie i kumulacja owej aktywności w naszym wnętrzu w ten sposób, iż nasze duchowe siły osiągnęłyby określony stopień napięcia (Kraftspannung) ${ }^{55}$, który prowadziłby następnie do „koncentracji” naszego ducha w nim samym oraz na tej drodze do swoistego jego pogłębienia (zentrale Vertiefung des Geistes) $)^{56}$. Owo pogłębienie naszego ducha nie jest jednak możliwe, jeśli „wzięciu w nawias” nie ulegną nie tylko poszczególne treści poznawcze, którymi „karmi się" nasza świadomość, lecz również konkretne momenty naszej egzystencji, a mianowicie te, gdy nasza duchowa aktywność koncentruje się bardziej „na zewnątrz”, a w tym sensie "poza" nami, tj. poza naszym źródłowym ja. Chodzi tutaj zatem o prze-

51 E. Husserl, Idee fenomenologii. Pięć wykładów, przeł. J. Sidorek, PWN, Warszawa 1990, s. 76. Swoje Wesensschau Husserl porównywał również do poznania intelektualnego opisywanego przez Mikołaja z Kuzy. Charakteryzując istotę poznania racjonalnego pisał „Wyżej od tego racjonalnego poznania znajduje się intelektualne [ujęcie rzeczy - M.A.], które «ratio sine dissensu», «visio mentalis», «intuitio». To wszystko zdaje się być niczym innym jak wglądem ejdetycznym" (E. Husserl, Husserliana. Erste Philosophie (1923/1924.) Erster Teil: Kritische Ideengeschichte, Bd. VII, Martinus Nijhoff, Haag 1956, s. 330).

52 Por. HAU VI, op. cit. 60; E. Husserl, A V 22, Universale Ethik. Wissenschaft und Leben. Wissenschaft und Ethik - Theorie und Praxis, mythische und wissenschaftliche Weltbetrachtung; Philosophisches Leben (1931), s. 49 (dalej MS A V 22).

53 Por. E. Wolz-Gottwald, Transformation der Phänomenologie. Zur Mystik bei Husserl und Heidegger, op. cit., s. 153.

54 HAU XLII, op. cit., s. 236; MS A V 21, op. cit. s. 54; Por. E. Wolz-Gottwald, Die Transzendentale Phänomenologie und die philosophische Mystik. Zum Durchbruch eines neuen Denkens im Spätwerk Edmund Husserls, op. cit., 104-105.

55 HAU XLII, op. cit., s. 236; MS A V 21, op. cit. s. 54.

56 Por. Ibidem. 
kroczenie siebie na drodze już nie tylko spekulatywnych ćwiczeń, ale także ściśle duchowych praktyk w swoim sposobie bytowania ${ }^{57}$. Inaczej mówiąc, celem niniejszych zabiegów jest przezwyciężenie naszego "ja powierzchniowego" (das obere Ich) $)^{58}$, które w porządku ontologicznym jest naszym "ja niższym" (niedriges Ich) ${ }^{59}$ na rzecz "ja wyższego" (das höhere Ich ${ }^{60}$, tj. „ja głębinowego" (unteres Ich) ${ }^{61}$. Tym, do czego tutaj dochodzi, jest po prostu swoiste "zawężanie” ludzkiego ducha w jego bytowaniu jedynie do „prawdziwej i rzeczywistej sobości” (die wahre und wirkliche Selbst $)^{62}$ człowieka tak, aby ten został sam na sam ze sobą samym, osiągając tym sposobem wewnętrzną pustkę. Przy czym, jeśli wzięciu w nawias podlegać ma nasze ",ja powierzchowne”, to redukcję fenomenologiczną można odczytywać w gruncie rzeczy również 4/ jako rodzaj ćwiczenia się człowieka $\mathrm{w}$ jego umieraniu. To właśnie być może $\mathrm{z}$ tego względu filozof nadmienia w jednym ze swych pism krótko, iż celem fenomenologicznej pracy podmiotu nad sobą samym byłoby ostatecznie osiągnięcie mistycznego stanu bycia niezwiązanym (ledig) - niezwiązanym z niczym, tj. także sobą samym ${ }^{63}$. „Prawdziwym obowiązkiem jest bycie niezwiązanym (...) i nie stanowi to żadnej przyjemności" ${ }^{64}$, dodając gdzie indziej "cała cnota realizuje się w tym, by siebie samego jako osobę zapomnieć" ${ }^{65}$. W tym sensie człowiek musi przeżyć „transcendentalną śmierć" samego siebie (der transzendentale Tod) ${ }^{66}$, tj. musi zdobyć się na akt negacji i wyparcia się siebie - siebie w swej nieautentyczności i swym wewnętrznym zakłamaniu. Przy czym owa duchowa śmierć człowieka musi być tutaj zarazem tożsama z jego „transcendentalnymi

57 Por. Eckard Wolz-Gottwald, Transformation der Phänomenologie. Zur Mystik bei Husserl und Heidegger, op. cit., s. 108-109.

58 HAU XLII, op. cit., s. 423; MS A V 21, s. 18.

59 HAU XLII, op. cit., s. 468.

60 Ibidem.

${ }^{61}$ HAU XLII, op. cit., s. 423; MS A V 21, op. cit., s. 18.

${ }^{62}$ HAU VI, op. cit., s. 264.

63 Teorię bycia niezwiązanym z niczym twórczo rozwijali Mistrz Eckhart oraz inspirujący się jego myślą autor średniowiecznego traktatu Teologia Niemiecka. Obaj rozpatrywali oni ów stan w świetle koncepcji Abgeschiedenheit (por. Mistrz Eckhart, Kazania, przeł. W. Szymona, „W drodze”, Poznań 1986; idem, Traktaty, przeł. W. Szymona, „W drodze”, Poznań 1987; Frankfurtczyk, Teologia niemiecka, przeł. P. Augustyniak, Fundacja Hrabiego Cieszkowskiego, Warszawa 2013). Co ciekawe, na ewentualne podobieństwa między redukcją fenomenologiczną, a refleksją Mistrza Eckharta zwraca również swoją uwagę B. Welte (Por. B. Welte, Meister Eckhart. Gedanken zu seinen Gedanken, Herder Verlag, Freiburg 1979).

64 HAU XLII, op. cit., s. 397; MS A I 21, op. cit., s. 90.

65 E. Husserl, MS F I 24, Formale Ethik und Probleme der ethischen Vernunft (1909-1923), s. 47 (dalej MS F I 24).

66 Idem, Zur phänomenologischen Reduktion. Texte aus dem Nachlass (1926-1935), Bd. XXXIV, herg. S. Luft, Kluwer Academic Publishers, Dordrecht: 20002, s. 475 (dalej HAU XXXIV). 
narodzinami" (transzendentale Geburt) ${ }^{67}$, tj. momentem, kiedy ten zradza siebie $z$ niego samego do nowego bycia. $W$ jej wyniku danym jest mu zaczać przecież wieść życie, które jest „życiem ukonstytowanym z wnętrza"68 niego samego, gdyż mającym swe źródła jedynie w jego "pra-ja”, do którego, na drodze „ogołocenia” jego własnego bytu najpierw z wszystkiego tego, co względem niego zewnętrzne i względne, a następnie pod pewnym określonym względem również i z niego samego, doprowadziła go właśnie redukcja fenomenologiczna. W tym też sensie „(...) gdyby pojmować narodziny (Geburt) pewnego ja, a w tym momencie koniecznie ja śpiącego czy przytomnego, a w każdym razie stającego się przytomnie życia, jest możliwe do przyjęcia, że po śnie u początku (jeśli sen powinien być początkiem dopiero rodzącego się ja) wszelako musi nadejść przytomność" ${ }^{\prime \prime 9}$, która identyczna jest z naszą całkowitą wewnętrzną przemianą, umożliwiającą nam osiągnięcie siebie w pełni swego bycia i totalności własnej osoby. Doświadczając mianowicie śmierci samego siebie nie czynię nic innego jak raz na zawsze „ukonstytuowuję siebie wewnętrznym wartownikiem" (mich als inneren Posten ansetzen $)^{70}$ mego bytu, który trwa ze sobą samym w szczególnego rodzaju „wewnętrznej zażyłości” (eigene Innerlichkeit) ${ }^{71}$, gdyż stałą osią wydarzania się jego egzystencji jest tylko i wyłącznie jego autentyczne ja ${ }^{72}$.

Stawiając przed człowiekiem zadanie powolnego oraz stopniowego ćwiczenia się $\mathrm{w}$ konstytuowaniu siebie podług prawdy własnego bytu, fenomenologia bywa miejscami odczytywana przez jej twórcę jako rodzaj "wewnętrznej praxis" (innere praxis) ${ }^{73}$ oraz "troski o samego siebie" (Selbsterhaltung) ${ }^{74}$ człowieka. Bowiem zadanie, jakie stawia ona przed nami, to zadanie wydobycia czy wręcz "wyłuskania” z najgłębszych pokładów nas samych, na drodze zarówno spekulatywnych jak i duchowych praktyk, naszego „pra-ja”, „z" którego i „w" którym powinna wydarzać się cała nasza egzystencja, gdyż tylko wtedy można powiedzieć, iż faktycznie żyjemy "prawdziwie własnym życiem”

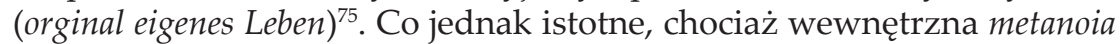
człowieka, do której tutaj dochodzi, w znacznej swej części jest wynikiem jego długotrwałej oraz żmudnej pracy nad sobą samym przewidzianej

67 Ibidem.

68 HAU VI, op. cit., s. 116; por. E. Wolz-Gottwald, Transformation der Phänomenologie. Zur Mystik bei Husserl und Heidegger, op. cit., s. 114.

69 HAU XXXIV op. cit., s. 470.

70 HAU XLII, op. cit., s. 315, MS F 24, op. cit., s. 71.

71 HAU XLII, op. cit., s. 246; MS E III 9, op. cit., s. 22.

72 Por. E. Wolz-Gottwald, Zur Metabasis im Spätwerk Edmund Husserls, op. cit., S. 122.

73 HAU XLII, op. cit., s. 213.

74 MS B I 21 (4), op. cit., s. 40.

75 HAU VI, op. cit., s. 258. 
w ramach redukcji fenomenologicznej, to - jak sam Husserl o tym wspomina - jest ona ostatecznie „boską łaską"76. Oznacza to, iż fenomenologia $w$ naszym stawaniu się sobą jest zdolna doprowadzić nas jedynie do pewnej określonej granicy, której przekroczenie nie jest już zależne od naszych skończonych, ludzkich sił. W tym też sensie filozof mówi tutaj o tym, iż człowiek zostaje raczej "wciągniętym” (hineingezogen) ${ }^{77}$ w swoją wewnętrzną przemianę, zdając sobie zarazem sprawę, iż tym samym przed jego fenomenologią otwiera się perspektywa jakiegoś „,ponadracjonalizmu" (Überrationalismus) ${ }^{78}$, którego nigdy wcześniej nie był on świadom. Zdaje się jednak, że tak musiało być, skoro w przekonaniu Husserla nasze „ukryte ja" 79 jest tożsame z „wiecznym Dasein” człowieka, będącym - co więcej - naszym "ja etycznym” (ethisches Ich) ${ }^{80}$, które jako takie trwa w szczególnego rodzaju jedności z samym Absolutem.

\section{Jedność bytu skończonego z bytem wiecznym w ich działaniu na rzecz dobra. Teodycealny wymiar fenomenologii}

Postulowany przez Husserla wysiłek wycofania się człowieka do własnego wnętrza i osadzenia swojego istnienia w głębi swego bytu miał na celu nie tyle wycofanie się przez niego ze świata zewnętrznego i oddanie się jakiejś spekulatywnej czy kontemplatywnej formie życia, lecz szczególnego rodzaju działalność etyczną podejmowaną ",z" wnętrza nas samych, która będzie miała miejsce "tu i teraz". W tym kontekście pisał Husserl: „Nie poprzez życie pustelnicze, odosobnienie (Absonderungen), czyste, wzniosłe myśli i spekulacje, lecz poprzez działanie w społeczeństwie i na rzecz niego, realizuje się w pełni swój obowiązek (Pflicht), wypełnia człowiek prawdziwie swe przeznaczenie" ${ }^{\prime 81}$. Z kolei owym przeznaczeniem człowieka jest zadanie wydobywania wpisanego $\mathrm{w}$ naturę świata dobra.

„Naiwno-przytomne" bycie człowieka ma, zdaniem Husserla, to do siebie, iż temu zdaje się, że świat, ze względu na doświadczane przez niego ból oraz cierpienie, krzywdę oraz biedę, głupotę czy egoizm dru-

76 HAU XLII, op. cit., s. 236; MS A 5 21, op. cit., s. 54; por. K. Held, Lebendige Gegenwart, op. cit., s. 183.

77 HAU VI, op. cit., s. 104.

78 Ch. Jamme, Überrationalismus gegen Irrationalismus. Husserls Sicht der mythischen Lebenswelt, in: Ch. Jamme, O. Pöggeler, Phänomenologie im Widerstreit, Suhrkamp, Frankfurt am Main 1989, s. 76.

79 E. Husserl, A V 21, Ethisches Leben. Theologie - Wissenschaft (1924-1927), s. 49.

80 HAU XLII, op. cit., s. 307; MS F I 24, op. cit., s. 72.

${ }^{81}$ MS F I 24, op. cit. s. 47. 
giego człowieka, wreszcie możliwość jego własnego niebycia, przesycony jest na wskroś złem. Dlatego niejednokrotnie człowiek pragnie sobie samemu zadać pytanie, czy aby nie jest tak, że „(...) życie w świecie jest urojeniem; jest bezcelowe i nic z niego nie wynika? Nie potrafię mego życia oraz świata w społeczności ludzkiej ostatecznie afirmować. Mógłbym to uczynić jedynie wówczas, gdybym wierzył w sens świata. «Teoretycznie» nie mam «ku temu» żadnego powodu. Na gruncie doświadczenia niczego nie mogę tutaj wykazać (Kant); doświadczenie uczy, że jeśli czasami coś w pojedynczych przypadkach uda się zrealizować, w całości przecież jest to niemożliwym. Nic nie jest ostatecznie ważne, wszelka ostateczność jest względna" ${ }^{\prime 2}$. Owo doświadczenie zła przybrało na sile zdaniem fenomenologa zwłaszcza w XX-tym wieku, kiedy to w świetle utylitarystycznej oraz relatywistycznej wykładni naukowego światopoglądu, rzeczywistość została już zupełnie pozbawiona swej idealności, tj. „płaszcza nieskończoności jako nieskończonej doskonałości"83, którym okrył ją niegdyś jej Stwórca. Przy czym Husserl widzi w tej sytuacji jedynie jedno wyjście, bowiem nawet jeśli „świat lubi być piekłem i lubi sprowadzać ocenę znaczenia siebie samego w swej całości do braku jakiejś sumy końcowej pozytywnych wartości - do braku jakiejś niezmiennej pozytywnej ich nadwyżki [i w ogóle - M.A.] do braku jakiś trwałych wartości, ja opieram się temu piekłu i spełniam mój «obowiązek»" ${ }^{44}$. W ten sposób kolejny raz w myśleniu filozofa dochodzi do swoistego przesunięcia znaczenia fundamentalnych dla jego refleksji kategorii, gdyż Husserl zaczyna interpretować od tej pory ,ja powierzchowne" człowieka jako ",ja upadłe" (das verfallende Ich) ${ }^{85}$ lub wręcz jako „ja grzeszne" (sündiges ich) ${ }^{86}$, które zawiniło tym, iż bytując z samej swej natury „z dala" od naszego źródłowego ja, bo w pewnym sensie "poza” nim, sprawia ono, iż mijamy się z naszym absolutnym sollen, które określa ów najgłębszy wymiar naszego bytu. W ten sposób kategoria naturalnego nastawienia opisująca "naiwno-przytomne bycie” naszego "ja powierzchownego" nabiera w rozważaniach Husserla jeszcze szerszego antropologicznego znaczenia. Fenomenolog nie omieszka zdefiniować owego bycia nawet jako postaci duchowej choroby (Krankheit $)^{87}$, trawiącej od wewnątrz nasze nieautentyczne ja, które zdaje się w tym wszystkim być martwe już za życia, gdyż „Kto odstępuje od dobra jest tym niejako, który ulega śmierci (...). On w jakimś sensie praktykuje samo-

82 HAU VIII, op. cit., s. 355.

83 HAU XLII, op. cit., s. 429; MS E III 4, Teleologie, 1930, s. 6 (dalej MS E III 4).

84 Por. HAU XLII, op. cit., s. 310-311; MS F I 24, op. cit. s. 75.

85 HAU XLII, op. cit., s. 395; MS F I 24, op. cit., s. 52.

86 Ibidem.

87 Por. HAU XLII, op. cit. s. 301; MS F I 24, op. cit., s. 69. 
bójstwo (Selbstmord), żyjąc tak jakby owo samobójstwo usprawiedliwiał i przez to konsekwentnie dopuszczał się go"88.

Zapytać można byłoby jednak, dlaczego Husserl upiera się przy tym, iż w naturę świata wpisane jest raczej dobro, a niżeli zło? Dla fenomenologa odpowiedź jest tutaj prosta. Przekonany jest on mianowicie o tym, iż czystą wolą dobra (Wille zum Guten), a wręcz samym najwyższym Dobrem, które wciąż udziela się światu i nieustannie sobą go obdziela, jest Bóg ${ }^{89}$. „Najwyższym sensem bytu - pisał fenomeno$\log$ - jest dobro i to ono jest przedmiotem boskiej aktywnosci, na którą ukierunkowane jest całe boskie działanie. Boska aktywność jest boską wolą bycia rzeczywistą (Real-sein-Wollen Gottes)" ${ }^{\prime 90}$. Co jednak istotne, Husserl zakłada dynamiczną naturę Absolutu, sądząc iż Ten udzielając się światu tak, iż wszystko wręcz "tętni" Jego własnym życiem, wciąż się w swoim byciu dzieje, stając się coraz bardziej sobą. To z kolei nie byłoby możliwe, gdyby nie byt stworzony, "poprzez" który oraz "w" którym Absolut dąży do osiągnięcia swojej pełni. „Bóg - twierdził Husserl - jest wszędzie - boskie życie żyje we wszelkim życiu. (...) Cała rzeczywistość doświadczalna i każda postać skończonej duchowości są obiektywizacją Boga (Objektivation Gottes) - rozwinięciem boskiego działania (Entfaltung der göttlichen Tätigkeit)"' ${ }^{\prime \prime 1}$. W ten sposób jest On paradoksalnie doskonałością, która wciąż dąży do swojej entelechii - doskonałością jednak szczególną gdyż „(..) poza Nim nie istnieje «nic»; On konstytuuje wszystko, a irracjonalna materia nie jest ukształtowaną rzeczą lecz wciąż materią. Świat posiada swój sens z Boga, a ponadto jest «niczym»"92. W tym sensie wszystko istnieje "z" Niego i "dzięki" Niemu, chociaż On, pomimo iż Jego życie tętni ",w" tym wszystkim, jest niczym z tego ${ }^{93}$. Stworzenie bowiem nie jest jedynie przypadłością Boga, gdyż On nie jest jedna, wszechobejmującą wszystko substancją. Bóg jest "ponad" i „poza" wszelkim bytem, będąc jedynie absolutną Dobrocią i tak jak jest On najwyższym Dobrem, tak też wszystko inne jest jedynie dobre, będąc Jego epifanią. Tym, co z kolei wyjawia Go w sposób najdoskonalszy w świecie, jest sam człowiek, który w sposób świadomy oraz

88 HAU XLII, op. cit. s. 439; MS E III 4, op. cit., 16.

89 Por. HAU XLII, op. cit., s. 168; MS B II 2, op. cit., s. 27; Frakfurtczyk, Teologia Niemiecka, op. cit., s. 86-87. Pojmując Boga jako absolutne Dobro, które udziela się całemu stworzeniu, Husserl podąża - jak sądzę - tropem myślenia Frankfurtczyka na co wskazuje uderzające podobieństwo formułowanych przez niego myśli.

90 HAU XLII, op. cit., s. 168, MS B II 2, op. cit., s. 27; por. Frakfurtczyk, Teologia Niemiecka, op. cit., s. 86-87.

91 HAU XLII, op. cit., s. 168; Edmund Husserl, B II 2, op. cit., s. 27; Frakfurtczyk, Teologia Niemiecka, op. cit., s. 68.

92 HAU XLII, op. cit., s. 336-337; MS F I 24, op. cit., s. 41; por. Frakfurtczyk, Teologia Niemiecka, op. cit., s. 101.

93 Por. K. Held, Lebendige Gegenwart, op. cit., s. 183. 
dobrowolny, z własnej natury "ciąży” całym swym bytem ku dobru, pragnąc Go w świecie coraz bardziej pomnażać. Dlatego, wówczas kiedy odkrywam, a następnie urzeczywistniam w świecie na drodze swego etycznego działania dobro, można powiedzieć, iż „z własnej natury jestem zjednoczony z Bogiem, ponieważ kroczę po boskich ścieżkach"94, a owa jedność naszego działania, to jedność naszego chcenia, kiedy moja wola staje się swoistą możliwością ziszczenia się boskiej woli. „Bóg jako wola dobra - wyznawał Husserl - jest ostateczną rzeczywistością (...). W ten sposób Bóg osiagga swoją pełną realizację. (...). We wszystkim co jest szlachetne oraz dobre, które w sobie urzeczywistniam, jestem zatem spełniającą się boską wolą (...)"95.

Co ciekawe, egzystencja człowieka wydarzająca się z naszego „wiecznego Dasein”, którą Husserl będzie nazywał po prostu „życiem etycznym" (ethisches Leben) ${ }^{96}, \mathrm{w}$ jego przekonaniu otwiera zarazem nasz byt na doświadczenie nieskończoności do tego stopnia, że możliwym jest, iż na jej gruncie dojdzie do osiągnięcia unii mistycznej człowieka z Bogiem. Husserl wspomina bowiem o takim rodzaju zjednoczenia bytu skończonego z bytem wiecznym, kiedy ten co prawda współ-działa z Bogiem na rzecz urzeczywistniania dobra, współ-pragnąc jego dalszego ziszczania, ale to bardziej Absolut działa w nim, aniżeli on sam ${ }^{97}$. Człowiek w tym szczególnym momencie zostaje po prostu „przeniknięty" (hindurchdrangen) ${ }^{98}$ przez Boga, przez co jego byt ogarnia spokój, a cała dotychczasowa aktywność jego ducha ulega swoistego rodzaju „wyciszeniu" i „zawieszeniu”: „Teraz jestem wyciszony, teraz śpię - komentował całe zajście Husserl - po czym, kiedy skosztuję tego jedynego

94 HAU XLII, op. cit., s. 236; MS A V 21, op. cit., s. 54.

95 HAU XLII, 2014, op. cit., s. 168; MS B II 2, op. cit., s. 27; por. Frakfurtczyk, Teologia Niemiecka, op. cit., s. 68.

96 HAU XLII, op. cit., s. 321; MS F I 24, op. cit., s. 71. „Etyczna forma życia” człowieka to dla Husserla zarazem „życie rozumne”, gdyż „rozumnym jest moje życie oraz postępuje rozumnie w sferze praxis, wtedy kiedy chce tego, co najlepsze (...) kiedy kieruję wolą tak aby ta nie pozwoliła mi nigdzie indziej dążyć, nic innego czynić i nic innego chcieć jak tylko to, co najlepsze" (HAU XLII, 2014: 327; MS F I 24, 1931: 71). Tego typu idee życia etyczno-rozumnego zaproponowali nam zdaniem Husserla już Grecy, którzy mieli być przekonani o tym, iż między myśleniem a byciem człowieka, wiedzą a życiem etycznym zachodzi głęboki związek, bowiem rozum posiadając zdolność mierzenia bytu podług absolutnej prawdy, stanowi jako taki nie tylko normatywne źródło naszego myślenia, lecz również postępowania. Zaproponowany nam przez Greków sposób bycia fenomenolog nazywa "filozoficzną formą istnienia" bądź egzystencją „określoną przez rozum filozoficzny” (por. E. Husserl, Kryzys nauk europejskich i fenomenologia transcendentalna. Wprowadzenie do filozofii transcendentalnej, op. cit., s. 5 i 13).

97 Por. K. Held, Lebendige Gegenwart, op. cit., s. 182-183.

98 Por. HAU XLII, op. cit., s. 235; MS A 5 21, op. cit., s. 54; Frakfurtczyk, Teologia Niemiecka, op. cit., s. 68. 
w swoim rodzaju spokoju, powrócę do mego bycia aktywnym"99. W tym właśnie momencie to raczej „Bóg mówi w nas”100, a ja „,jestem kierowany" przez Niego (geleitet durch Gott) ${ }^{101}$ oraz to On ",we" mnie umiłowuje stworzenie, wskutek czego właściwie „przez moje serce, poprzez moje pulsujące życie przenika Jego życie - miłość Boga i Jego umiłowanie świata"102. Co więcej, unia mistyczna człowieka z Bogiem jako taka miała, w przekonaniu Husserla, skutkować zrodzeniem się ludzkiego bytu na jeszcze wyższym albo głębszym poziomie naszego ducha, aniżeli „życie etyczne", a to oznacza, iż Husserl dopuszczał jeszcze inny sposób bycia człowieka, ktory byłby ukonstytuowany w najgłębszym wymiarze jego bytu, jakim jest jego „autentyczne ja”"103, który określał on jako „życie błogosławione" (seliges Leben) ${ }^{104}$. Owo życie wiązałoby się dla fenomenologa ze zbawieniem (Seligkeit) człowieka osiagganym w bezpieczeństwie udzielanym mu przez Boga (die Seligkeit in Gottesgeborgenheit) ${ }^{105}$, będąc jednak jako takie swoistym pogłębieniem „etycznej formy życia”, aż do jej granic. Chodzi tutaj bowiem o zbawienie człowieka pojmowane jako nieskończona aktywność, tj. nigdy nie znajdujące swego kresu ani jakiegokolwiek wytchnienia "przedzieranie” (zerbrechen) się przez to, co w świecie przypadkowe oraz względne w stronę tego, co mu konstytutywne i przyrodzone ${ }^{106}$.

O ile "życie błogosławione" jest sposobem bycia, które z definicji musi być dostępne nielicznym, o tyle „etyczna forma życia” będzie zdaniem Husserla możliwością, która nie jest aż tak daleka człowiekowi, będąc przecież również pewną formą trwałego zjednoczenia człowieka $\mathrm{z}$ Absolutem $\mathrm{w}$ ich chceniu oraz działaniu. Jako taka, byłaby ona naznaczona działaniem na przekór "temu” światu, bądź złu, które wyjawia się nieustannie $\mathrm{w}$ nim, definiując nasz sposób jego przeżywania oraz percypowania. $\mathrm{W}$ ten jednak sposób owo bycie byłoby wyrazem heroicznej walki człowieka - walki, która jest niczym innym jak rodzajem teodycei oraz kosmodycei. „Walka (Kampf) - twierdził Husserl - z głupota, bezsensem i egoizmem. Także i to często podlega pojęciu przypadku. Wielki i piękny plan, ogromna praca życia mogą zostać zniweczone poprzez to, iż życie rozumne człowieka dobrego zostaje skonfrontowane z egoizmem i złośliwością drugiego. Wojna (Krieg), w której pada ofiarą

99 HAU XLII, op. cit., s. 235; MS A 5 21, op. cit., s. 54; por. Frakfurtczyk, Teologia Niemiecka, op. cit., s. 89.

100 E. Husserl, Husserliana. Aufsätze und Vorträge, Bd. XXVII, herg. S. Ijsseling, Dordrecht, 1989, s. 234.

101 Ibidem.

102 MS A 5 21, op. cit., s. 47.

103 HAU XLII, op. cit., s. 394; E. Husserl, A V 21, op. cit., s. 15.

104 HAU XLII, op. cit. s. 201; MS F I 24, op. cit., s. 71.

105 Por. MS B I 21 (4), op. cit., s. 33.

106 Por. HAU XLII, op. cit., s. 403 i 486. 
przede wszystkim to, co najlepsze. Teodycea. Kosmodycea"107. Co jednak ciekawe, owej wojny ze złem nie prowadzimy nigdy w pojedynkę, gdyż jako takie „życie etyczne” nie jest „,̇̇yciem etyczno-solipsystyczny$\mathrm{m}^{\prime \prime 108}$, lecz życiem wspólnotowym. Tym, co charakterystyczne dla owego "nowego" życia jest to, iż „etyczna wspólnota” (ethische Gemeinschaft) ${ }^{109}$, która na jego gruncie się konstytuuje, to wspólnota, w której pozostajemy wszyscy w sobie wzajemnie skryci (...), tak iż moje ,ja etyczne" „(...) nie tyle poza (außer), lecz w (in) innych żyje (poprzez (durch) ich własną wolę chce, poprzez ich własną [etyczną - M.A.] wartość działa), a w jedności i związku chcenia oraz bycia z innymi tworzy wspólnotę, która działa"110. Tym sposobem fenomenologia w przekonaniu Husserla miała umożliwiać zrodzenie się ogólnoludzkiej wspólnoty etycznej, która jest w gruncie rzeczy „etycznym związkiem między chrześcijaninem, a chrześcijaninem"111 - wspólnoty, która podejmując się teodycei, przynależy cała do Boga (Gottesmenschentum) ${ }^{112}$.

Próbując odczytać fenomenologię jako sposób autokonstytucji podmiotu - drogę ćwiczenia się we właściwym nam sposobie bytowania, którego źródłem byłoby właściwy nam status ontologiczny, tj. nasze „pra-ja”, próbowałam zwrócić uwagę, iż istnieje możliwość innej interpretacji fenomenologii aniżeli w duchu teorii poznania - interpretacji, która zdaje się być również w pełni zbieżna z zamysłem czy przynajmniej ogólnymi intuicjami jej twórcy. Idąc tym nowym tropem interpretacyjnym, fenomenologię należałoby rozumieć jako rodzaj pracy jej adepta nad sobą sa-

107 HAU XLII, op. cit., s. 317-318; MS F I 24, op. cit., s. 79.

108 HAU XLII, op. cit., s. 312; MS F I 24, op. cit., s. 76.

109 HAU XLII, op. cit., s. 314; MS F I 24, op. cit., s. 78.

110 Ibidem.

111 E. Husserl, Husserliana, Zur Phänomenologie der Intersubjektivität, Zweite Teil: 1932-1938, Bd. XIV, herg. I. Kern, Martius Nijhoff, Haag 1973, s. 175. W świetle teorii „etycznej wspólnoty „,, którą nakreśla nam tutaj Husserl dochodzi kolejny raz do przesunięcia znaczeń podstawowych dla jego myśli pojęć. Chodzi tutaj dokładnie o kategorie intersubiektywności oraz wczucia. Intersubiektywność jest bowiem od tej pory, mówiąc fenomenem oznaczającym to, co wydarza się między członkami „etycznej wspólnoty”, która ukonstytuowała się na gruncie wczucia, kiedy to jeden podmiot wczuwa się w drugiego, próbując z nim wspó-myśleć oraz współ-działać na rzecz dobra. Warunkiem jako takim owego wczucia dla Husserla jest miłość, stąd też „etyczną wspólnotę” będzie on nazywał „wspólnotą miłości (Liebesgemeinschaft)” (por. Ibidem, s. 175-176; A.A. Bello, A.A., The Divine in Husserl and other Explorations, op. cit., s. 55-56; U. Melle, Husserls personalistische Ethik, in: Fenomenologia della ragion pratica, herg. B. Centi, Napoli 2004, s. 353).

112 HUA XLII, op. cit., s. 176; MS A V 21, op. cit., s. 80. por. Klaus Held, Lebendige Gegenwart, op. cit., s. 183-184. 
mym, kiedy ten na gruncie ćwiczeń zarówno o charakterze spekulatywnym, jak i duchowym, próbuje "przedrzeć” się do samego siebie, aby doświadczyć siebie w źródłowości własnego bytu. W tym sensie można byłoby ją pojmować jako - jak sam Husserl o tym wspominał - rodzaj „wewnętrznej praxis"113 bądź, idąc jeszcze dalej, być może jako rodzaj techniki życia wewnętrznego, „wyłuskującej” to, co najbardziej w nas skryte i to, co zarazem jest nam najbardziej właściwe. Stąd też zasadne byłoby pytanie: czy w duchu takiej interpretacji nie należałoby w ogóle zmienić programowego zawołania fenomenologii, które winno brzmieć już nie tyle „z powrotem do rzeczy samej”, lecz „z powrotem do człowieka samego"? Przy czym nie może nam tutaj umknąć fakt, iż w przekonaniu Husserla nasze źródłowe ja miało być tożsame z „wiecznym Dasein” człowieka, będącym zarazem jego ,ja etycznym”, które z natury trwa w stałym nachyleniu ku dobru, znajdując się tym sposobem w szczególnego rodzaju jedności z Absolutem, który jest absolutną „wolą dobra” czy wręcz samym Dobrem wciąż ziszczającym się w świecie. W tym też sensie, doświadczenie przez człowieka siebie w faktyczności własnego bytu na drodze fenomenologicznego ćwiczenia się umożliwia mu zarazem wejście w szczególnego rodzaju komunię z Bogiem - jedność, która wyraża się ich współ-chceniu i współ-działaniu na rzecz dobra. To z kolei czyniłoby fenomenologię droga, która już nie tylko prowadzi nas do nas samych, lecz również i do Boga.

\section{Bibliografia}

Anders G., Die Schrift an der Wand, München 1967.

Avé-Lallemant E., Edmund Husserl zu Metaphysik und Religion, w: Husserl in Halle, H.M. Gerlach, H.R. Sepp (hrsg.), Franfurt am Main 1994, s. 85-108. Bello A. A., The Divine in Husserl and other Explorations, w: A.-T. Tymieniecka (herg.), "Analecta Husserliana" XCVIII.

Cairns D., Conversations with Husserl and Fink, The Hague 1976.

Chun Lo L., Die Gottesauffassung in Husserls Phänomenologie, Frankfurt am Main 2008.

Drisch H., Lebenserinnerungen, München 1951.

Frankfurtczyk, Teologia niemiecka, przeł. P. Augustyniak, Fundacja Hrabiego Cieszkowskiego, Warszawa 2013.

Held K., Gott in Edmund Husserls Phänomenologie, „Phaenomenologica”, 200 (5), s. 723-738.

Held K., Phänomenologische Begründung eines nachmetaphysischen Gottesverständnis, w: K. Held, T.Söding, Freiburg, 2009. s. 9-27. 
Held, K.,Lebendige Gegenwart, „Phaenomenologica 23, Haag: Martinus Nijhoff.

Husserl E. Medytacje kartezjańskie, przeł. A. Wajs, PWN, Warszawa 1982.

Husserl E., Filozofia jako nauka ścista, przeł. W. Galarowicz, PWN, Warszawa 1992.

Husserl E., Idee czystej fenomenologii i fenomenologicznej filozofii, przeł. D. Gierulanka, PWN, Warszawa.

Husserl E., Kryzys nauk europejskich i fenomenologia transcendentalna. Wprowadzenie do filozofii transcendentalnej, przeł. S. Walczewska, Papieska Akademia Teologiczna, Kraków 1987.

Husserl E., List Edmunda Husserla do Arnolda Metzgera, „Przegląd filozoficzny „,, Warszawa 2009 (18), s. 537-543.

Jägerschmid A., Rozmowy z Edmundem Husserlem (1931-1938), przeł. Z. Abrahamowicz, „ZNAK”, 1972 (212), s. 153-185.

Jamme Ch., Überrationalismus gegen Irrationalismus. Husserls Sicht der mythischen Lebenswelt, in: Ch. Jamme, O. Pöggeler, Phänomenologie im Widerstreit, Suhrkamp, Frankfurt am Main 1989, s. 65-80.

Keilbach W., Zu Husserls phänomenologischen Gottesbegriff, w: W. Keilbach (herg.), Religion und Religion. Gedanken zu ihrer Grundlegung, Verlag Ferdinand Schöninsch, Paderborn 1976.

Landgrebe L., Husserls phänomenologischer Zugangsweg zu den Problemen der Religion, in: W. Härle, E. Wölfel (herg.), Religion im Denken unserer Zeit, Elwert, Marburg 1986 s. 5- 72.

Melle U., Husserls personalistische Ethik, in: Fenomenologia della ragion pratica, herg. B. Centi, Napoli 2004, s. 327-355.

Mistrz Eckhart, Kazania, przeł. W. Szymona, „W drodze”, Poznań 1986.

Mistrz Eckhart, Traktaty, przeł. W. Szymona, „W drodze”, Poznań 1987.

Welte B., Meister Eckhart. Gedanken zu seinen Gedanken, Herder Verlag, Freiburg 1979.

Wolz-Gottwald E., Zur Metabasis im Spätwerk Edmund Husserls, „Allgemeine Zeitschrift für Philosophie,, 1995 (101), s. 11-130.

Wolz-Gottwald E., Die Transzendentale Phänomenologie und die philosophische Mystik. Zum Durchbruch eines neuen Denkens im Spätwerk Edmund Husserls, „Philosophisches Jahrbuch,,, 101 (1994), s. 98-115.

Wolz-Gottwald E., Transformation der Phänomenologie. Zur Mystik bei Husserl und Heidegger, Passagen Verlag, Wien 2009.

E. Husserl, Husserliana (Hau), Gesamte Werke.

Hau VI Band VI, Die Krisis der europäischen Wissenschaften und die transzendentale Phänomenologie. Eine Einleitung in der phänomenologische Philosophie, Haag 1953.

Hau VII Band VII, Erste Philosophie (1923/1924) Erster Teil: Kritische Ideengeschichte, Haag 1956.

Hau VIII Band VIII, Erste Philosophie (1923/1924) Zweiter Teil: Theorie der phänomenologischen Reduktion, Haag 1959.

Hau XIV Band XIV, Zur Phänomenologie der Intersubjektivität, Zweite Teil: 2932-1938, Haag 1973. 
Hau XXXIV Zur phänomenologischen Reduktion. Texte aus dem Nachlass (1926-1935), Dordrecht: 20002.

Hau XLII Band XLII, Grenzprobleme der Phänomenologie. Analysen des Unbewusstseins und der Instinkte. Metaphysik. Späte Ethik. Texte aus dem Nachlas (1908-1937), Dordrecht 2014.

Hau XXVII Band XXVII, Aufsätze und Vorträge, Dordrecht, 1989.

Hau Dok Dokumente Band III/IV, Briefwechsel. Die Freiburger Schule, Dordrecht 1994.

Hau Dok Dokumente Band III/VII, Briefwechsel. Wissenschaftlerkorrespondenz, Dordrecht 1994

Hau Dok Dokumente Band III/IX, Briefwechsel. Familienbriefe, Dordrecht 1994.

Manuskrypty

A V 21, Ethisches Leben. Theologie - Wissenschaft (1924-1927).

A V 22, Universale Ethik. Wissenschaft und Leben. Wissenschaft und Ethik-Theorie und Praxis, mythische und wissenschaftliche Weltbetrachtung; Philosophisches Leben (1931), s Teleologie, 1930.

B II 2, Absolutes Bewusstsein.Metaphysisch (1907-1908).

B I 21 (4), Wissenschaft und Leben (...) Weg in die Philosophie von der Praxis her. Wissensbelege (...) Der Mensch als europäischer, die Umwelt als wissenschaftlich umgestaltete, die Kultur eine wissenschaftliche. Wissenschaft und Tradition. (...) Der griechische Mensch und seine Wissenschaft (1924-1925).

B I 21 (5) Meditation (1933).

E III 4, Teleologie, 1930.

E III 9, Enthüllungsgang der universalen Teleologie als Gang der gesamten Konstitution von den Anfängen an, 1930-1931.

MS F I 24, Formale Ethik und Probleme der ethischen Vernunft (1909-1923).

\section{Fenomenologia procesem autokonstytucji}

\section{Słowa kluczowe}

Autokonstytucja podmiotu; „,wieczne Dasein”; redukcja fenomenologiczna; Bóg; dobro

W świetle licznych, chociaż całkowicie rozproszonych wypowiedzi Husserla, fenomenologię - co być może dziwi i zaskakuje - można odczytywać jako proces autokonstytucji podmiotu we właściwym mu byciu. Tym sposobem fenomenologia byłaby już nie tylko - jak przyzwyczaiła nas do tego jej wykładnia w duchu teorii poznania - metodą mającą umożliwić jej adeptowi widzenie jasne i niczym niezmącone, lecz procesem wydobywania właściwego nam statusu ontologicznego. Szczególne narzędzie owej pracy na rzecz wydobycia z nas naszego „ukrytego ja” - ,ja prawdziwego i autentycznego" stanowiłaby z kolei redukcja fenomenologiczna, która w przekonaniu Husserla umożliwia nie tylko 
dekonstrukcję tego, co można byłoby nazwać świadomością potoczną człowieka, lecz dekonstrukcję jego nieautentycznego sposobu bycia. Jako taka redukcja fenomenologiczna byłby bowiem narzędziem zwrotu i stopniowego „wchodzenia" podmiotu do jego własnego wnętrza - narzędziem złożonego procesu osadzania całej jego duchowej aktywności wewnątrz jego bytu, w wyniku czego dochodziłoby koniec końców do "koncentracji” jego ducha w nim samym i przezwyciężenia jego „,ja powierzchniowego", podług którego ten egzystuje w codzienności swego bycia. W tym świetle można byłoby być może postrzegać fenomenologię jako rodzaj „wewnętrznej praxis” czy wręcz techniki życia wewnętrznego. Przy czym owo „ukryte ja”, którego wydobycie jest celem fenomenologicznej pracy jej adepta nad nim samym, jest niczym innym zdaniem filozofa jak naszym „wiecznym Dasein”, pozostającym w szczególnego rodzaju związku z Bogiem, gdyż związku współ-chcenia dobra i współdziałania na rzecz jego nieustannego pomnażania w świecie.

\section{Phenomonology as auto-constitution, or a process of growing of an object to its unique existence? Discussion around antropological-mystical motives of Edmund Husserl's work}

\section{Keywords}

Auto-constitution of the subject; „,eternal Dasein”; phenomenological reduction; God; goodness

In the light of many dispersed statements of Husserl - a fenomenology could be seen as a process of an self-constitution in its own way of existing which are proper for it. In this way, the fenomenology would be not only - as it is often underlines in the framework of an epistemic paradigm of its interpretation a method of a clear and undisturbed look, but also a process of capturing of the appropriate ontological status which. A unique tool of this work in order to elucidate an "hiden I" - the „real and authentic I" would woule be a phenomenological reduction which - in Husserl's opintion - makes possible not only a deconstruction of the so-called "common awareness", but also a deconstruction of a non-authentic way of a human being. As such a one - the phenomenological reduction would be a tool of a self-reference and a gradual penetration of a subject of its own „inside". It would be a tool of founding of its whole spiritual activity inside its „esse". In result, it would finally imply an concentration of its "spirit" in itself and a kind of overcoming of its ",superficial I" being a pattern of its contemporary existance. In this light one could consider a phenomenology as a kind of an internal "praxis" or even a technique of the internal life. By the way, this "hiden I", which elucidating is a goal of the phenomemological work is nothing more - due to Husserl - than our "eternal Dasein", remaining in a unique relation with God; it is a kind of co-grasping and co-acting for a "goodness" and its permanent increasing in the world. 